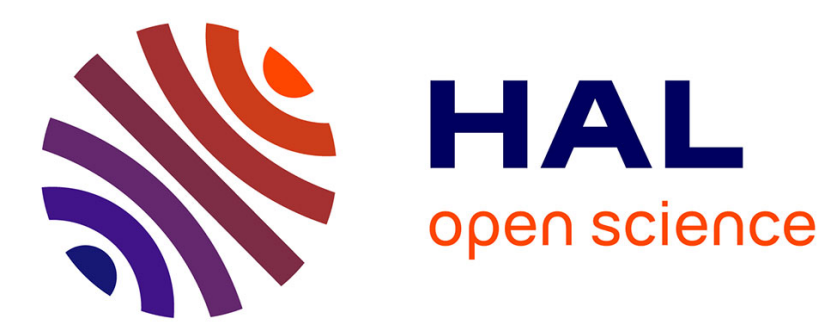

\title{
Polarization-resolved REMPI spectroscopy of the 5p-6s Rydberg transitions in CF3I
}

J. Mastenbroek, C. Taatjes, G. van den Hoek, S. Stolte, V. Skorokhodov

\section{To cite this version:}

J. Mastenbroek, C. Taatjes, G. van den Hoek, S. Stolte, V. Skorokhodov. Polarization-resolved REMPI spectroscopy of the 5p-6s Rydberg transitions in CF3I. Journal de Physique IV Proceedings, 1994, 04 (C4), pp.C4-722-C4-722. 10.1051/jp4:19944200 • jpa-00252662

\section{HAL Id: jpa-00252662 https://hal.science/jpa-00252662}

Submitted on 1 Jan 1994

HAL is a multi-disciplinary open access archive for the deposit and dissemination of scientific research documents, whether they are published or not. The documents may come from teaching and research institutions in France or abroad, or from public or private research centers.
L'archive ouverte pluridisciplinaire HAL, est destinée au dépôt et à la diffusion de documents scientifiques de niveau recherche, publiés ou non, émanant des établissements d'enseignement et de recherche français ou étrangers, des laboratoires publics ou privés. 


\title{
Polarization-resolved REMPI spectroscopy of the 5p-6s Rydberg transitions in CF3I
}

\author{
J.W.G. MASTENBROEK, C.A. TAATJES, G. VAN DEN HOEK*, S. STOLTE and \\ V. SKOROKHODOV**
}

Laser Centre and Department of Chemistry, Vrije Universiteit, de Boelelaan 1083, 1081 HV Amsterdam, The Netherlands

* Molecular and Laser Physics, Department of Physics, Catholic University of Hijmegen, Toernooiveld, 6525 ED Nijmegen, The Netherlands

** Institute of Physics, St. Petersburg State University, ul. Ulyanovskaya 1, Petrodvorets, St. Petersburg 198904, Russia

\footnotetext{
The 5p -6s Rydberg excitation in CF3I is studied using a $(2+1)$ REMPI scheme, with polarization and mass resolution. All of the two-photon-allowed electronic states in the manifold have been detected. Polarization analysis allows determination of non-totally symmetric vibrational frequencies in the excited states as well as the electronic symmetries of the states. Evidence is seen for interaction with other (likely valence) electronic states, especially in the upper spin-orbit components.
} 